\title{
Freedom and Responsibility
}

\section{S. R. Bhatt ${ }^{1}$}

() ICPR 2018

The present paper is an exercise in self-awareness and self-realization by a thoughtful human mind with regard to a very problematic but highly significant enigma of human life concerning the antinomy of freedom and determinism experienced in our concrete day-to-day living in the context of human behavior due to fragmented approach to life and Reality and need for the management of the same in a holistic framework. In this endeavor, we may derive helpful guidance and redemption from the deep insights and enlightening visions of Indian seers and sages. In a meaningful enterprise, the entire wide and variegated Reality is to be kept in view with the main focus on human existence. It has to be a holistic reflection from varied perspectives and multiple approaches. It has to be done with the objective of being benefited by it in shaping the cosmic and human existence for universal well-being. Naturally therefore the individual human existence, human society, natural environment, scientific and technological enterprises and socio-political organizations, etc., become crucial points in a purposeful deliberation. Consideration of deeper issues concerning these areas provides it practical orientation in the context of human life planning, social engineering, science policy and environmental stewardship.

\section{Human Being as Highest Emergent}

Human being is the highest emergent in the cosmic process so far. Shaped by genetic endowment, ecological interaction and cultural transformation human existence are multi-relational, multi-dimensional and multi-layered. It has individual, social and cosmic aspects in a holistic and organismic framework. It is intimately related with Nature, other human beings and non-human living species. Human identity, therefore, cannot be determined by any one of these facets alone in isolation from others; it is constituted by the totality and intricate unity of all of them.

\section{S. R. Bhatt}

srbhatt39@gmail.com; jicpr.editor@gmail.com

1 Indian Council of Philosophical Research, New Delhi, India 


\section{Human Being as Rational, Free and Responsible Agent}

Human being, ideally speaking, is ratiocinative, goal-oriented, free and responsible agent. He/she is a knower $(j \tilde{a} a t \bar{a})$, responsible agent (kartā) and enjoyer (bhoktā) through innate competence and overt performance. As a self-conscious and reflective person he/she has the capacity to understand one's own self as also others. The term used in Indian culture for such a human being is purușa. And his/her planned, purposive and methodical action is termed as purușārtha (human enterprise and accomplishment). As jinatā human being is endowed with the capacity to know, to discriminate and to form judgment. He/she has freedom of will and can make a choice. He/she is also a responsible agent and has to be accountable for his/her actions. The free will is regulated will. All his/her willful actions should therefore be in the form of purușārtha. He has to perform actions with full knowledge, freedom and responsibility. They should be in the form of artha (conducive and leading to well-being) and not anartha (detrimental and harmful). Activity is the law of life and every human being must act as purușa for survival, sustenance and for enhancement of quality of life. So there is inclusive alternation between freedom and determinism. Rationality as discriminative ability implies freedom to choose but being guided by certain norms. It also implies responsibility for the consequences so generated by ones actions. The point is that we have to avoid dichotomous approach to freedom and determinism.

\section{Meaning and Significance of Human Life}

Human life is unique and special gift which is rare among all the creatures. It is a prized possession acquired through a good deal of meritorious acts in the previous birth(s). It is valuable and is to be valued. A mechanistic understanding of human nature is truncated and cannot explain the spontaneity, creativity and goal-orientation inherent in human nature. Only a teleological, holistic and inclusive understanding of human potentialities, capabilities and achievements can do justice to human aspirations. The knowledge and quest for values and planned efforts to realize them constitute the core of ideal human life. All human beings must participate or made to participate in the process of value-realization. This is our universal responsibility.

\section{Constitution of Human Being}

Human being is an intricate psycho-physical complex animated and enlivened by spiritual principle called soul or self. There are varied understandings of human constitution in different cultures and disciplines of knowledge, but the VedicUpanișadic understanding in terms of five sheaths (pañcakośa) is most helpful. They are annamaya (physical), prānamaya (vital), manomaya (mental), vijñānamaya (intellectual) and annandamaya (spiritual). Among these five the physical and vital are material, mental and intellectual are quasi-material, and they are termed as 
psychical, and spiritual $(a d h i+\bar{a} t m a)$ is transcending these four which are empirical. There is simultaneity as well as hierarchy in them and there is a fine balance in this. It is a very neat and useful classification. But it should be kept in mind that all these five are integrally correlated and cannot be separated. Their distinction is only for classified understanding and practical purposes. In order to understand human nature our attempt should be to know the nature, functioning and interrelationship of all these five in a holistic framework. The fine and subtle constitution of physical body and conative senses, the wondrous play of vital breaths, the wonderful functioning of senses, the marvelous functioning of mind and cognitive senses, the brilliant displays of thoughts, emotions, feelings and volitions are all amazing and astounding, but we have to know all these. The functioning of human mind is astonishing. It is something more than a live computer. But much more significant are beatitudes and bliss of consciousness, the spiritual principle. We at the present juncture of our knowledge and capabilities may have only partial or faltering understanding of all these marvels of human life, but we must steadily continue our efforts to enhance our knowledge.

\section{Significance and Complexity of Human Sociability}

Sociability is built in human existence and human nature. Our social dimension is highly complex, complicated and subtle network of relations. Society provides the ground and sustenance for human existence and also for the basic structure and materials for human evolution. The lowest unit of society is family which may be joint or single, but the former has been the traditional form and it has served very useful purpose for smooth happy life in a corporate spirit of mutual care and share. It is called kutumba, a replica of viśva, a mode of coexistence in interdependence and interrelation, a supportive mutualism with a spirit of selfsameness. In this samghajīvana or corporate living the roles of grandparents, parents, children and grand children are well defined by socio-cultural norms. In this context the role of paramparā or live tradition is significant. Paramparā is a live tradition deeply embedded in the past, well-footed in the present and envisioning the bright future. It is the accumulative process of transmitting, adjusting and applying the norms and values cherished in a culture. It admits of creative freedom and innovative changes.

\section{Meaning and Significance of Culture}

Tradition is rooted in culture. Culture is a mode of being, a pattern of living, a set of commonly shared values and belief patters and practices. It is a complex whole comprising knowledge, beliefs, conduct, morals, laws, custom, artistic, scientific and technological pursuits, humanities and social sciences. It is a total heritage borne by a society. It contributes to the discovery of meaning of life. Therefore, culture has to enhance, enrich, enlarge and encourage the fullness of life, health of the body, delight of the mind, and plenitude of peace and bliss. 


\section{On understanding svarajya (Freedom)}

It has been a lesson of history that no nation can grow and advance, survive and thrive if its key concepts and guiding principles get fossilized, twisted and distorted and its intellectuals lose the capacity of creative reinterpretation of its past heritage and tradition to suit the new and changing circumstances and their requirements and aspirations. Like the concept of Dharma, etc., the concept of Svarājya has been pivotal to Indian modes of thinking and ways of living right from the Vedic times, though of course its original and basic connotation has become oblivious to us. It will not therefore be a futile and worthless exercise to attend to its proto-meaning and restate the rich and profound ideas inherent in it.

Our present day usage of the word Svarājya along with its colloquial formulation $S v a r a \bar{j} j$ has come in practice as a vernacular translation of the English word "Independence" which has a predominant, if not exclusive, political overtone. Though it is not wrong to use this word in this narrow and restricted sense with proper stipulation, it is advisable to be aware of its original spiritual meaning of which cultural, moral, political, economic, etc., are only derivatives.

The present delineation is first to put forth the foundational spiritual and metaphysical aspect of this term in the want of which there cannot be adequate understanding and appreciation of this rich, multifaceted and multi-layered concept. It envelops within its sweep the individual, society, and the cosmos at large. Thus, we can think of Svarājya of individual, of different social formations and organizations, and finally of the entire cosmos. Apart from these layers it has metaphysical, moral, social, political, economic, and cultural and many other dimensions. All these are organically interrelated and in a holistic framework the realization of the one cannot be complete without realization of the other.

At the outset a distinction is to be drawn between Svarājya, svarāj and surāj . $S v a r a \bar{j} j$ and $s u r \bar{a} j$ are political concepts. The former stands for self-rule or selfgovernance, and the later stands for good governance, whether it is self-governance in the form of democracy or any other form of governance. Svarāj need not necessarily be $s u r a \bar{j} j$ and vice versa.

Svaräjya, as stated earlier, is much wider and more profound. It is derived from the root rājr (diptau, to shine). One who possesses Svarājya is svarāt. Svarājya is a state of being svarāt. In the Upanișads by the technique known as "Chandas Dīrgham,” it is formulated as Svarājyam (Svarājah bhavāḥ Svarājyam).

Etymologically it may mean Svena rājate (i.e., existing by itself or self-luminous). Another etymology can be "Svasmin rājate" (i.e., existing in oneself, selfsituated). Any real entity having this characterization is svarāt. The prefix sva may mean "one's own" or it may also mean anandam. So sva/svah/svar means bliss. The state of svātantrya (its synonym) is being self-situated, self-luminous and blissful. It is called svarloka where bliss prevails. Bliss is said to be the aspiration of all existence. It is the inherent nature as well as summum bonum of all existence. It is an authentic existence having an intrinsic and inherent worth. This is the goal of Yoga (Tadā dṛștuh svarūpe avasthānam). 
Two things must be made clear. From the metaphysical point of view only an Absolute (if we believe in this idea) can be svarāt, but from the empirical point of view since every existence partakes this nature of the Absolute, it is potentially svarāt. Otherwise every empirical existence has dependent origin and interdependent existence in corporate and associated living (samgha jivana). This is the sum and substance of the teachings of the Upanișads and Nāgārjuna. Secondly, it is not that conscious being or human alone is or can be svarät. This property has to be extended to all material existences as well. In this sense it means recognition of intrinsic worth of Nature also in contrast with the present day tendency of exploiting Nature out of ignorance or selfish materialistic considerations. Íśvarakṛșna, the Sāmkhya thinker, has highlighted this facet of Matter when he talks of mukti of Prakrti. Sri Aurobindo also talks of ascent of matter to supra-mental state.

This idea that every existence has an intrinsic nature and in the cosmic process this must be realized, this has been the vision of the Vedic seers. In the holistic and organicismic approach to Reality the Vedic-Vedāntic thought has maintained that the ultimate nature of Reality is unitary and sui generis (Ānidavātam svadhaya tadekam) and it gets diversified out of its own free will (Ajāyamano bahudhā vijāyate; So akamayat eko'ham bahusyāmii). Whether it is the state of natura naturata or of natura naturan, the ultimate Reality is independent, as it is second to none in the Vedāntic framework. In the cosmic process (viśva) there is mutative world (jagat) which is multiplicity arising out of, contained within and sustained by and subsumed under one unifying Whole (Tajjalān). The Whole (Brahmānda) is independent, self-existing and blissful, and each individual part (pinda) within the Whole is also independent (pūrnāt pūrnamudacyate) in so far as everyone is svarät but the only difference is that the independence of parts within the Whole is seasoned and conditioned by interdependence and limitations. Every part depends upon other parts at one level and upon the Whole at another level, but this interdependence does not come in conflict with or mar the independence of each part if the process is normal and well regulated. Each has its distinct nature and role and can enjoy its independent and authentic existence within the Whole. In an organicismic approach there is no dichotomy of "exclusive either-or." Only if we give up this perverted attitude, we can have the unitary vision. This is the nature of Reality given to us in pure experience as corroborated by the Vedic seers and Upanișadic sages.

Svaräjya constitutes the very essence of Reality whatever be its conception. (It is preferable to use the word freedom rather than independence because of its positive connotation.) It consists in realization of freedom or self-being. In this sense freedom is the summum bonum of all existences. It is a state of perfection. It is both freedom from and freedom to. But it is only to be experienced and not to be conceptualized or verbalized. This is metaphysical freedom, the ultimate Svaräjya.

It is in this background one has to understand and approach the concept of "Freedom" (Svarājya/svātantrya) in Indian context. Freedom constitutes the very core (svabhāva) of Reality, say the Vedic seers. Whether it is the Vedic conception of describing it as Anidavatam svadhaya tadekam (i.e., That One Ultimate Being which exists by itself independently) or the Buddhist account of Tattva as prapañchaśunya, the ultimate nature of all existence is freedom. The phenomenal nature is due to dependent origination and interdependent existence, which is not original and final. 
It is a state of circumscription of freedom. But every entity has the innate instinct and potentiality to realize freedom which consists in getting back to its pristine nature (Svarūpavasthāna in Yoga and Pratyabhijñā in Kashmir S'aivism). It is in this sense the Sāmkhya thinker Íśhvarkrșhṇa talks of freedom not only of Puruṣa but also of Prakriti. Whatever be the account of the nature of final destiny conceived variously, it consists in realization of freedom. In this sense freedom is the sumum bonum of all existence. To repeat, it is a state of existence which can only be experienced and cannot be expressed and described. This is metaphysical freedom.

\section{Svarajya in Ideas}

In the context of academic sphere in India when we are to rethink about Svarājya, the most pertinent aspect that should demand our attention immediately and urgently is Svarājya in ideas, a freedom from intellectual slavery, a cultivation of authentic Indian rationality which can be called genuinely Indian, which springs from our soil, which is rooted in our psyche, and which meets our needs and aspirations. It is a tragic incident of history that because of centuries of slavish existence Indian intellectuals have become flunkeyist and in spite of 70 years of political independence we are still languishing under intellectual slavery. Our system of education which we have inherited from the Britishers has made us to wear a mask which has not only made us appear a foreign $b \bar{a} b u$ to our masses of people, it has also clouded our thinking so much so that we think in alien terms, about alien issues, in alien methodology mistaking them as our own. We employ adapted language, borrowed phraseology, superimposed models and unnatural modes of thinking and ways of living, thinking that these are marks of progressiveness and modernity. We are cut off from our roots and feel ashamed to adhere to our traditions even though they may be healthy and conducive to our well-being. For fear of being branded as conservative, orthodox, obscurantist, etc., we are afraid of being associated with our past and crave to cling to alien thoughts, beliefs and practices which demean our existence and make it inauthentic. Let it be made clear that there is nothing wrong in adopting English as a language, or borrowing all that is true, good and beautiful elsewhere, but we have to keep our feet firm in the native soil. We have to keep our mind and eyes open to the world to assimilate all that is desirable and healthy, but we should solidly stand on our feet and should not allow ourselves to be swept away. This is what the Vedic seers enjoined and Mahatma Gandhi averred.

Prof. K. C. Bhattacharya in his seminal paper "Svarāj in Ideas" has lamented long back as to how our thoughts have become "hybrid through and through and inevitable sterile slavery has entered into our very soul." Referring to the colonization of our mind and hybridization of our ideas as one of the most distressing features, he points out that, "We either accept or repeat the judgments passed on us by western culture, or we impotently resend them, but have hardly any estimate of our own ideas wrung from our inward perception." He observes that "India's native soul gets twisted and warped by a shadow mind due to western education" imposed on us but also willingly accepted by us with a slavish mentality. In his view "Slavery begins when one ceases to feel the evil and it deepens when the evil is accepted as good." 
He rightly warns that "Intellectual bondage is more enslaving than political subjugation because of its invisibility and silent creeping paralyzing power, unforgivably persist even after political independence." Of course he is for cultural assimilation, but he opposes cultural subjugation. He writes, "There is cultural subjection only when one's traditional cast of ideas and sentiments is superseded without comparison or competition by a new cast representing an alien culture which possesses one like a ghost." Prof. Bhattacharya has argued that "reaffirmation of cultural traditions is the heart of all authentic anti-colonialism" and that "our intellectual inheritance needs renewal and reorientation." He feels that "the traditional storehouse of truth can serve our civilization's needs better than imported knowledge and experience." So he pleads for the "conservation of distinctive values evolved through ages of continuous historical life of Indian society." There has to be a creative use of the past but as our understanding has become contaminated we have lost our capacity to understand our past. There is a need for reawakening, but unfortunately we are at present incapacitated to do so.

It is high time that we give a halt to and give up this intellectual slavery and cultural superimposition. What we need to day is creation of a new class of intellectuals which can bring about resurgence in the field of ideas. The need is to create new intelligentsia that has ability to overcome the alienated intellectuals of India. Prof. K. C. Bhattacharya opines that "The most prominent contribution of ancient India is in the field of philosophy." He writes, "It is in philosophy, if anywhere, that the task of discovering the souls of India is imperative for the modern India." But our mode of doing philosophy at present is doing history of philosophy and not philosophy proper. What is needed is doing darśana or tattvajñāna with pramāna and prayojana. This has to be one of the items in rethinking about Svarājya.

In worldly existence political freedom becomes foundational. All other facets of freedom depend on this. If political freedom is lost, all other freedoms are jeopardized. But to safe guard political freedom preservation of ideological freedom is most essential. If intellectual freedom is lost, all other freedoms get endangered. This is what ancient Indian thinkers exhorted and made Kṣātra Teja subservient to Brāhma Teja. The greatest slavery is flunkeyism. Prof. K. C. Bhttacharya emphasized "Svarāj in Ideas." His views on this subject are both instructive and inspiring. Mahatma Gandhi also highlighted this point. It is hoped that young Indian mind will pay heed to this. It is unfortunate that even after 70 years of political independence, we have not been able to achieve intellectual freedom. We have remained flunkeyist. It is high time that our young minds cultivate Svarājya in ideas.

\section{Worldly Freedom}

The Svarajjya that is meaningful and significant for a human being in the worldly state of existence is the individual and social freedom of which cultural, moral, political, economic and other types of freedom are various dimensions. Freedom along with ratiocinative consciousness, creativity and responsibility constitutes the essence of a human being. For a human being freedom is very life and soul. That is why Lokmanya Tilak declared it to be our birth right. Freedom alone provides 
socio-politico-economic integrity to a human being. Without freedom she/he is as good as dead though alive physically. If human life is just for eating and sleeping, and having clothing and shelter, it is not worthy and meaningful. Only freedom provides dignity and worth to human being. That is why in the history of human civilization we find thousands of people sacrificing their lives for the sake of freedom not only for themselves but also for others, their country and people. We have examples of Maharana Pratap Bhagat Singh, Sukhdev and many others in Indian history. They also knew the value of their life and of others. Life was dear to them, but they sacrificed their lives because they thought that they would rather die than live worthless and servile life subjected to others. Of course physical life is precious and dear and people do yearn for a long life in good health, but freedom cannot be bartered with life in slavery. Physical life is valuable but more precious is dignity of life.

\section{Two Aspects of Worldly Freedom}

There are two aspects of freedom which are essential and complementary to each other. One is freedom from all limitations, restrictions, etc., which are detrimental to ones legitimate well-being and development. It stands for absence of undue interference from others, of constraints or domination or control or coercion by others. It also means freedom from wants, pain and suffering. Classical Indian thinkers talked of three types of suffering and absolute freedom there from. They longed for freedom which is named as mukti. The other aspect is positive, that of being free to act in such a way as to enable one to realize one's potentialities in the best possible ways. It means scope to realize one's inherent potentialities. So freedom is not just absence of external constraints but also availability of objective conditions and practical opportunities for self-realization. Proper education alone is the surest means for this (Sā vidyā yā vimuktaye).

\section{Freedom, Consciousness and Creativity}

Human beings' concrete demand for freedom is cognized by consciousness, and creative activity to cognize and transform human and cosmic existence is also due to consciousness. So freedom and consciousness go together. Because of freedom, creativity and consciousness human feels to be superior to other living beings empowered by them. He/she also tries to manage Nature. By virtue of the possession of freedom, ratiocinative consciousness and creativity human being approaches the world not fatalistically but creatively, not passively but actively, to reshape the world not blindly but purposefully and deliberately. Human history has been history of struggle of this type of freedom. All pursuits of science and technology, humanities and social sciences, art and literature have been ideally engineered in this direction only. The transformation of Human, society and Nature are the legitimate objectives of human endeavor. For this it is essential that every individual, every society, every nation and all that come under it should have freedom, which means svarāja 
in ideas or thought, svātantrya in action, svāvalambana in self-governance, svadeshi in economy, svasāmarthya in self-defense, etc.

\section{Freedom, Equality and Justice}

Freedom, equality and justice are commensurate with one another. Human being is a social creature. Only in a social context and in a social framework freedom is meaningful. There are three foundations of sociality, viz., coexistence (sahavāsa), cooperation (sahakāra) and mutual caring and sharing (sahabhoga), and this is possible only in a complementary situation of freedom, equality and justice. Equality and justice do not diminish or curtail freedom rather they make freedom available to all. Equality of opportunity and distributive justice thus constitute two pillars to provide solid foundation to freedom and social solidarity. Freedom and equality are commensurate with each other. Human is a social creature. Only in a social context and social framework where there is sahavāsa, sahakāra, and sahabhoga, freedom is meaningful. This implies mutual care and share which is possible only in a complementary situation of freedom, justice and equality. Equality and justice do not diminish freedom, rather they make freedom available to all. This has been the keynote of many Vedic Rchas and averments of the Upaniṣads and the Gītā.

\section{Freedom, Rights and Duties}

If the commensurability situation is to be obtained, and it ought to be obtained for peace and prosperity, then it is imperative that there should be system of rights and duties (Ṛnas and Mahāyajñas) embedded in a democratic framework of society and state. Only in a democratic mode of thinking and living well regulated by dharma in the traditional sense which is sustaining (dhāraka), regulating (niyāmaka) and enhancing principle (sädhaka) of life, rational and free humans can pursue the kind of life best suited to themselves without hurting or thwarting the similar expectations and aspirations of fellow beings. A dharma-based democratic approach (Dharmocracy) is organicismic in which individual well-being is tied up with social wellbeing. It is not either individualistic or totalitarian. It maintains a smooth and fine balance between personal integrity and public interest. It recognizes the value of humans as an end also and not just as means or resource, by reconciling individual self-development and social harmony and progress and world peace.

If each individual is to enjoy a modicum of freedom and be protected from unwarranted trespass, then the interrelation among individuals must be defined by a system of rights and obligations. Likewise, the structure and limits of social organizations should also be so defined and designed as to preserve and promote the primary value of freedom. The relation between freedom and rights is reciprocal. If one is not free one cannot enjoy freedom or fight for freedom. On the other hand, rights safeguard individual's freedom. In the same way the relation between rights and obligations is also reciprocal. " $\mathrm{A}$ " has freedom to do " $\mathrm{x}$ " if and only if " $\mathrm{A}$ " has a right to do so and every one other than "A" has an obligation not to impede "A" in 
the exercise of his/her freedom. But "A" also is under obligation not to act illegitimately but to act to help and not hinder in the realization of rights of others. By way of extension the same reciprocity obtains between individual freedom and social authority. Freedom is not license, and it has to be circumscribed by social authority. One cannot take freedom to be unconditional. It is only in the context of and within the contours of social authority that freedom can be preserved and enjoyed. Thus, freedom means freedom of an individual in society. A human's freedom is carved out in relation to his/her fellow beings. But essentially it is to be understood in terms of his/her awareness of one's legitimate needs and aspirations, potentialities and capabilities, and scope to exercise choice and options to realize the objectives set forth for a meaningful life as conceived in the theory of purușārthas.

\section{Freedom and Authority}

Freedom is not license, and it has to be circumscribed by social authority. Freedom and authority are not incompatible. We cannot take freedom to be unconditional. It has to be within the contours of social authority. Thus freedom means freedom of an individual in society. A human's freedom is carved out in relation to others. But it is also to be understood in terms of one's awareness of one's needs, and aspirations, potentialities and capabilities, and scope to exercise choice and options to realize the objectives set forth for ones meaningful existence. For all this authority is a means. And just realization of freedom is an end. The need of authority is due to our demand for freedom. So authority cannot be designed independently of our cherished goals of freedom. In this context a distinction is drawn in Classical Indian thought between "an authority" and "in authority." "An authority" is impersonal dharma as expounded by brähma teja and "in authority" is the ruler a person or body of persons which puts the authority in use (Kșātra teja).

Interdependence between freedom and authority is rooted in the social and gregarious nature of human being. Authority is a means, and just realization of freedom is an end. Authority is designed from the perspective of freedom. Whether authority is a matter of historical evolution or social contract is not a significant issue in this context. What is significant here is to know that the need of authority is due to our demand for freedom. So authority cannot be said to be designed independently of our cherished goals of freedom. The point to be noted and emphasized is that keeping the end (i.e., freedom) constant we have to vary the means (i.e., authority) in the light of the degree of protection it is required to give to freedom. In this context the distinction drawn between spiritual authority and temporal power, an authority and in authority becomes meaningful. "An authority" is impersonal law, custom, tradition, etc., but "in authority" is a person or group of persons who puts the authority in operation and use. There is always a possibility of a person in authority making a misuse of authority. A person in authority may be selfish, dishonest, corrupt, inefficient or short tempered or having other evil qualities. Therefore, there must be adequate provisions and sufficient checks for dismissing such persons or making them relinquish such authority. Existence and acceptance of an authority resulting in surrendering some degree of personal freedom should only be in exchange for or to 
secure guaranteed security of life and betterment of living and if this is not provided by the person in authority who is bearer of an authority, people have every right to oppose and remove him/her. In any good system of governance, there should be adequate mechanism for such a correction.

It has always been an unfortunate occurrence of history that there have been more often than not conflicts between individual freedom and socio-political authority. In dictatorship, monarchy, oligarchy, totalitarianism and even in democracy such situations often arise. However, in an ideal framework of relationship, this can only be regarded as mishap or aberration to be corrected or overcome. The tension between the two cannot be said to be natural or irresoluble. There is a need and scope for conflict-resolution, a democratic liberal welfarism, which I call as Dharmocracy, and which can be said to be most congenial and conducive mode of governance that alone can ensure enjoyment of freedom in true sense.

\section{Democracy to be Seasoned with Dharma}

All is not well in the political arena in the world as it is smeared with violence, terrorism, nepotism and corruption. Though it must be admitted that democracy is the best form of governance evolved so far, it cannot be said to be the best. As Winston Churchill once remarked, "No one pretends that democracy is perfect or all-wise. Indeed it has been said that democracy is worst form of government except all those other forms that have been tried from time to time." (Hansard, November 11, 1947.) There is lot of truth in what Churchill opined. All the three wings of democratic framework, viz., legislature, executive and judiciary are vitiated with several ills and evils all over the world where democracy prevails. This calls for serious rethinking about functioning of democracy. We may have to think going beyond democracy, if need be. Going beyond does not mean rejecting the basic spirit or merits of democracy which are laudable. It only means rejecting all that is not good and beneficial, that which is detrimental to wellness, that which is harmful. Out of several possible alternatives "Dharmocracy" can be considered. Views of contemporary Indian thinkers like Mahatma Gandhi, Acharya Tulsi, Acharya Mahapragya, Jaiprakash Narayana, Deendayal Upadhyaya and others can be helpful in this regard.

\section{Freedom and Doctrine of Karma}

Coming to the moral sphere Indian thinkers have put forth doctrine of Karma to ensure freedom and responsibility. This theory has for centuries exercised an unmitigated and pervasive influence on Indian psyche. It is based on two presuppositions. One is presumption of an order in the moral sphere on causal pattern. The second is the belief in the nature of individual self as a ratiocinative, free and responsible agent to whom attribution of action and retribution of consequences are to be apportioned. Freedom of will is implicit in the notion of moral responsibility. Such a freedom is the intrinsic character of moral agent whose actions are necessarily preceded by free choice. Free agent can be negatively understood as one who does not act under duress, constraint or 
compulsion. Its anti-thesis is acting freely. The word "free" has different meanings in the context of volition and action. In the case of volition it is freedom from extraneous influences in choosing "A" instead "B," etc. In case of freedom of action it is freedom to do which has been chosen by the agent which implies availability of means to do "A." The former entails the distinction between svatantra kartā (free agent) and niyojya kartā (employed agent). The latter distinguishes between upalabdhi or anupalabdhi of sādhana (availability or non-availability of means).

\section{Responsibility as Corollary of Freedom and Need for Ethics}

Coming to the issue of responsibility, it is a corollary of and ensues from freedom. As stated earlier, Philosophy is systematic reflection on our lived experiences with a view to be profited from it and one of our most problematic experiences is human behavior which is indeterminate and unpredictable but concerning which paradoxically constant endeavor is made for determination and regulation. Since all pollution and perversion are human making, there is need to regulate human conduct. The discipline of ethics is primarily concerned with postulation of norms for good human life and regulation of human conduct in accordance with these norms. On the presumption that human being is a rational, free and responsible agent ethical considerations, ethical theorizing and ethical judgments are undertaken. It is hoped and believed that human conduct can be regulated and be made norm-abiding. This is the objective of the discipline of ethics. Of course, there is always a gap between theory and practice and our endeavor should be to bridge it as far as possible. A moral norm may not be adhered to in its totality or fullness, but this does not mean that it should be given up as impracticable or utopian. The distinction between mahâvrata and anuvrata in the Jaina tradition is a good guide in this regard. The mark of an ideal being actually perused is harmony between the inner and outer reality of the agent, between inner feelings and outward behavior. But this cannot be a fool-proof criterion. Public vigilance helps in norm-following.

Another point to be referred to is that norms are posited to be pursued (They are sādhya and not asādhya). In ideal situation they are to be practiced spontaneously as a matter of habit or by the force of conscience. But in practice it may not be so. That is why importance of moral education is accepted as it helps in cultivation of moral will. But more often than not because of moral infirmity built in human nature there is a need of external sanctions, social or political. That is why codes and laws are formulated. But this enforcement from outside is always feeble as moral weakness is ingrained in human nature. That is why there is greater need for moral education and constant vigilance. But it should not be overlooked that values are not to be taught but to be imbibed.

\section{Ethical Values (Virtues)}

Rationality as discriminative ability implies freedom to choose but being guided by certain norms. The determination and choice of alternatives requires norm-prescription but human freedom also implies a scope for both norm-adherence and 
norm-violation. Values to be pursued and disvalues to be shunned are both equally central to moral considerations.

Quest for values, pursuit of values and realization of values have to be holistic and integral exercises. They have to pertain to different dimensions of human constitution, as for example, analyzed in the pañcakośa theory of the Taittirīya Upanișad. Each dimension of human existence is valuable and must be catered to in a balanced and graduated manner. This is the message of this Upanișad. There should not be lopsided endeavor, concentrating on one and excluding the rest. Similarly human existence is situated in multi-layered environment and all layers are to be catered. Human being exists in family, in social and natural surroundings. The Śāntipātha in the Upanișads refers to many such layers. Values pertain to each of these layers. The value schema should not be regarded as partite or divisible. Al values in the schema are intertwined and possess inseparability. No one value can be realized without the rest. There is organic unity in the total reality, and this is reflected in value schema as well. In Classical Indian thought, this organic understanding was built-in but now under the impact of western civilization we have neglected it. In our value considerations, we have to go back to the classical thought if we are sincere and honest in our enterprise. We have talked a lot about values, particularly in the context of valueoriented education, without caring about the nature of reality given to us in our concrete experience. The reality we talk about is not the lived reality but abstracted reality, rationalized reality, and therefore we are far away from concrete reality. It is high time that we shad away our bias against Classical Indian thought, revisit Classical Indian thought and do so in a positive and constructive frame of mind. The contemporary mind is looking for new intuitions, fresh insights and innovative thinking and Classical Indian thought has the potentiality to provide the needed guidelines provided we understand it in its true spirits. The onus of responsibility for this guidance lies on young creative Indian minds, and it is hoped that they will prove to be worthy of this task.

\section{Knowledge of Values}

Our awareness of values is always prescriptive. It is different from the descriptive awareness concerning facts. A description can be true or false or doubtful, but the logic of prescription has another set of values. A prescription can be good or bad or indifferent. It may be conducive to well-being or harmful or of no effect. A description has to be local with the possibility of universalizability, but a prescription has to be global with the need of being applied to local situations. Accordingly the mode of knowing prescription cannot be the same as the mode of knowing the description. Of course both are to be grounded in experience but the nature of experience cannot be the same. The ideals are conceived in and spring from actual situation, but their source is not sense experience. 


\section{Private and Public Values}

So far as the question of values in private life and public life is concerned, in a holistic and integral approach the public-private divide is not entertained. Values are to be posited and pursued for both the spheres and they are to be sought conjointly. Public life is more demonstrable and loss of values can be detected with greater ease. External sanctions can operate with greater force. But value-pursuit is a collective and corporate endeavor. It is not a single person enterprise. There has to be an all round effort for this. It is physical-mental-spiritual exercise. It is a yajña to be performed by the collectivity for the collectivity. This is the message of the Vedas and the Upanișads. We have this cultural heritage available to us, and it is for us to look to it and be benefited by it.

\section{Professional Values}

Activity is the law of life and every human being has to act for survival, for sustenance and for enhancement of quality of life. So, human conduct has to be teleological and goal-oriented. In the choice of conduct, there is freedom as also regulation of freewill. There is inclusive alteration between freedom and determinism. Rationality as discriminative ability implies freedom to choose but being guided by certain norms. It also implies responsibility for the consequences so generated by ones actions. Freedom to choose means availability of alternatives to opt for that which is good, right and conducive to well-being or to opt for that which is bad, wrong and harmful to well-being. A human being can act in either of the two ways, but he has to be responsible for that action. This determination and choice of alternatives requires norm-prescription but human freedom also implies a scope for both norm-adherence and norm-violation. In this context ethical considerations become meaningful since they tell us about the rules and regulations to be adhered to and prohibitions to be avoided. Values to be pursued and disvalues to be shunned are both equally central to moral considerations. In ethical context values are termed as virtues and this relation between values and virtues should be kept in mind.

\section{Need for Multiple Professions}

Every human being has to undertake some profession for survival, for self-fulfillment and for social obligation. It has to be performed for self-expression, for selfenhancement and for self-realization. But its immediate aim is to earn livelihood. Every profession for its proper and efficacious performance has to depend upon several factors which may be regarded as its guiding principles. To determine these guiding principles, there is need professional ethos, regulations and management. A broad criterion of end-means-modalities-result can be considered.

Human needs and aspirations are multiple. This requires a variety of vocations and professions. Every human being cannot undertake all the vocations and perform 
all the functions of every profession. So, inter-professional and intra-professional ethos and management are needed to regulate them. All professions are meant for universal well-being, and we have the universal responsibility of upholding their purity and respectability. Unfortunately we seldom care for this. Every profession has to work out its own norms and regulations keeping in view the ultimate goal of cosmic well-being. A professional ethics is a management ethics. It pertains to the management of a profession in the sense that it regulates knowledge, will, skillful performance and distributive enjoyment of outcome of that profession. Proper education is the only means to achieve this. This education need not be a formal class room education. It can be imparted in very many ways and suiting to that profession and can be devised accordingly. Here some areas can be taken up for consideration.

Every rational human being has to undertake some profession or the other for survival, for self-fulfillment and for social obligation. It has to be performed for selfexpression, self-enhancement and self-realization as an ultimate objective, but its immediate aim is to earn livelihood. In an ideal situation there has to be a balance between the ultimate and the immediate objectives, but very often this is overlooked. This calls for professional ethos, regulations and management.

Every profession for its proper and efficacious performance has to depend upon several factors which may be regarded as its guiding principles. There are several criteria on the basis of which the guiding principles can be classified. The most important criterion is the distinction of end-means-modalities-result (sädhya-sädhanaitikartavyatā-phala). Every profession is meant to serve some goal, to realize some purpose and to attain some result. It is the basic requirement of every profession to have clarity about the end for which it is to be pursued. An absence of clarity or confusion about the goal very often results in improper or immoral performance.

There is a quadruple principle of knowledge-will-action-result for proper performance a profession. The agent in a profession has to know the knowledge-will-actresult relationship (jñanna-icchä-kriyāa-phala). If he/she is knowledgeable of this, he/she is a fit and competent person (adhikāri) to undertake that profession. Then only there can be skillful performance of that profession. Role of knowledge is foundational and pivotal. Lack of knowledge is harmful and detrimental to well-being. In all cultural traditions of India, the significance of knowledge is highlighted. But mere knowledge is not enough. It has to generate will and fructify in effort and action. If someone claims to know but does not have a will to act, that knowledge is unripe or incipient or false pretext. In the Pūrva Mīmāmsā, it is emphasized that Śăbdībhāvana must lead to Ārthībhāvanā and then only yajña can be said to have been performed. Knowledge generates will and this stirs up an agent to act, but his/ her power lies only in performance of action and not on the results of action. The human being has control on the performance of action and not on the accruing of its results. This is another type of professional management.

The Gita ideal of anāsakta karma or karmayoga is performance of Brahmaya$j \tilde{a} a$. It provides a blueprint for professional ethics as it comprehends properly both the quadruple principles referred to above. A proper management of these quadruples has been the keynote of the Bhagavadgìtā and Pūrva Mīmāmsā which provide a foundation of professional ethics. 
Performance of any profession has to be in the spirit of yajña or universal responsibility understood in the spirit of Yajurveda of which Ísāvāsyopanișd is the concluding part. This is the meaning of yajña in the Gītā as well. A yajña is a collective and corporate action for the sake of general well-being (Brahmārpana). Brahma stands for totality. Every profession is to be undertaken not for ones selfish end only (idam na mama). It is for vyaști, samaști and parameșți all the three, though apparently it is done for one's own self. So the result of action is to be surrendered to the totality $(s v \bar{a} h \bar{a})$. Every existence is a part of the corporate whole and is integrally related to the whole and its parts. There is fundamental unity of all existences. The basis of yajña is in satya and dharma which are rooted in rta. They are at the base of the cosmic process and sustain it. The cosmic process itself is a yajña. These are the subtle and sublime ideas not to be taken in their ordinary mundane meaning. They are to be understood in the context of the Vedic Samhitās and Brähmanas in $\bar{a}$ dhyātmika sense. They provide foundation to Indian spirituality which is holistic, integral and unitary approach to reality. These are rich concepts pregnant with profuse meaning for universal well-being. It is unfortunate that in the course of vast temporal span and due to exigencies of history they have lost their original meaning, got distorted and misused. But they need to be re-understood. No culture can survive and thrive if its seminal ideas, key concepts and fundamental doctrines get fossilized and sterilized. Macaulay realized this fact and tried to strike at the very roots of Indian culture and we are witnessing its evil consequences. But it is high time that we become alive to reality.

In the cosmic set up there has to be multiplicity of professions depending upon the needs and aspirations and abilities of the human individual. These professions keep on evolving and dissipating as the societies change. On account of human limitations and large number of wants, there is a need for multiplicity of professions. All professions are equally useful and valuable and therefore they should be treated at par, but it is human selfish nature to prioritize them and to put them in a hierarchy. It is a part of professional ethics to respect all professions and to follow the maxim of "Work is Worship." All professions are meant for universal well-being, and we have the universal responsibility of upholding their purity and respectability. Unfortunately, we seldom care for this.

Every human individual cannot perform all the actions and fulfill all the wants by himself/herself, and therefore there has to be choice of vocations. This should depend upon ones capacity, ability, interest and need. The Gītā calls it as svadharma. Everyone has to mind ones svadharma. This is professional ethics. Every profession calls for a code of conduct for its proper performance. The code stands for a set of rules and regulations regarding the two types of quadruples referred to above. There rules and regulations are to be both intra-profession and inter-profession. The Gītā emphasizes both these types of professional ethics. Generally we tend to side track inter-professional ethics and mind only intra-professional ethics. In modern times most of the professions have become inter-professional. For example, medical profession has preventive and curative aspects, but it is also intimately related with pharmaceutical, engineering, business, dietary, legal, psychological and many other professions. 
There can be as many professional ethics as there are professions. Some professional regulations are common to all professions and cut across all of them in spite of their varied nature, modes of functioning, objectives, etc., but they also require some separate or distinct set of norms as per their specific requirements.

Every professional ethics is management ethics. It deals with proper and effective management of that profession. This can be realized by proper education. This education need not be formal class room education. It can be imparted in many ways suiting to that profession. But this much is certain that without management there cannot be proper performance and without education there cannot be proper management.

\section{Conclusion}

Education is a conscious, deliberate and planned process of modification in the natural growth and development of human being and the surroundings. If proper and adequate, it ensures accelerated processes of development in human life in right rhythm. It is therefore a means for betterment and enhancement of quality of life. It is useful for personality development, character-building, and for livelihood. It is a hall mark of civil society. But all this becomes utopia if it is not properly conceived and implemented.

These and related issues may be taken up for threadbare analysis. But apart from theorizing practical concerns must be paramount. Knowledge without action is futile. In the Indian tradition it has been emphasized that right knowledge (samyak jūana) has to fructify in right conduct (samyak cāritra) In Jainism great emphasis is laid on proper knowledge (samyak jñāna). Knowledge is the only and surest way to spiritual perfection. The Jaina scriptures therefore emphasize that we must draw a

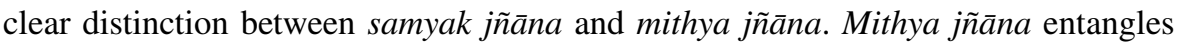
us in the vicissitudes of worldly life. It is bewitching and bewildering and it springs from avidya or ignorance. In order to have right knowledge right attitude or right mental make-up is necessary. This is samyak drsțti. Opposed to this is mithya drști with which we generally suffer. Samyak drști leads to samyak jũana, and the latter alone is the path way to mokșa. Mithyā drști and mithyā jñāna do not serve any genuine purpose and hence they must be discarded. For an aspirant of moksalmukti only samyak drsțti and jūana are helpful. This is the main theme of the teachings of the Agamas. Samyak jñana always leads to samyak cāritra. The value and purpose of knowledge is not theoretical but necessarily practical. Right conduct ensues only from right knowledge. Conduct without knowledge is blind and knowledge without conduct is lame. The two are complimentary to each other. And therefore knowledge has to lead to the corresponding conduct. Without right conduct deliverance from worldly miseries, trials and tribulations is impossible and without complete deliverance from these no permanent happiness can be achieved. As said earlier, these are the three jewels of life which every human being must wear. But this wearing is not decoration but actual practice and concrete realization. However, this is not easy to achieve. It requires tapas and sādhanā, a rigorous control of body, will and mind. So knowledge without conduct is useless. Merely listening to the discourses 
is wastage of time and futile. It does not help us in any way. What is needed is the ensuing conduct. But unfortunately most of us forget this. We listen to the sermons of the spiritual persons but do not practice them. We take it as a past time or a matter of routine of life. Our knowledge remains mere information at the mental level. The Dasavaikālika sūtra (IV) compares a person having knowledge without practice to a donkey who carries burden of sandal wood without knowing its value or utility. As the donkey bears the burden of sandal wood but has no share in the wealth of his load, similarly a person without practice merely bears the burden of his knowledge. He cannot enjoy spiritual progress which is the real fruit of knowledge. Instead he indulges in evanescent and fleeting worldly pleasures which invariably end up in pain and suffering or mental unhappiness or a feeling of vanity of life. The $\bar{A}$ vaśyakaniryukti also avers the same that knowledge is useless without conduct and conduct is useless without knowledge. In Indian culture, philosophy and religion, view and way, theory and practice, are not divorced and segregated. Darśana is not mere reflection upon the nature of reality but also a quest for and a realization of values. Basically it is a mokșa śāstra. There is a definite purpose in life and reality if we care to know and a definite goal to achieve if we have a will to do so. Our existence is not meaningless. It has a value and significance. But we must first of all know what we are, what is the nature and purpose of life, what we should be in our life and how we can be so, etc. The aim of human existence should be spiritual perfection through material progress. But material progress is only a means and not an end. The end is self-realization which is achieved through the removal of karmic matter and liberation from samsāra. There is potential divinity in human being and there must be effort for divinization. This is the ultimate teaching of all Indian scriptures (Āgamas). 